\title{
Bench to bedside review: therapeutic modulation of nitric oxide in sepsis - an update
}

\author{
Simon Lambden(1)
}

\author{
Correspondence: spl48@cam.ac.uk \\ Department of Medicine, \\ Addenbrooke's Hospital, Cambridge \\ University, 5th Floor, Cambridge \\ CB20QQ, UK
}

\begin{abstract}
Nitric oxide is a signalling molecule with an extensive range of functions in both health and disease. Discovered in the 1980s through work that earned the Nobel prize, nitric oxide is an essential factor in regulating cardiovascular, immune, neurological and haematological function in normal homeostasis and in response to infection. Early work implicated exaggerated nitric oxide synthesis as a potentially important driver of septic shock; however, attempts to modulate production through global inhibition of nitric oxide synthase were associated with increased mortality. Subsequent work has shown that regulation of nitric oxide production is determined by numerous factors including substrate and co-factor availability and expression of endogenous regulators. In sepsis, nitric oxide synthesis is dysregulated with exaggerated production leading to cardiovascular dysfunction, bioenergetic failure and cellular toxicity whilst at the same time impaired microvascular function may be driven in part by reduced nitric oxide synthesis by the endothelium. This bench to bedside review summarises our current understanding of the ways in which nitric oxide production is regulated on a tissue and cellular level before discussing progress in translating these observations into novel therapeutic strategies for patients with sepsis.

Keywords: Nitric oxide, Sepsis, Septic Shock, Arginine, Asymmetric dimethylarginine, Citrulline, Tetrahydrobiopterin
\end{abstract}

\section{Background}

\section{The discovery of nitric oxide}

Nitric oxide (NO) was the first endogenous gaseous signalling molecule to be discovered and was the product of work undertaken over an extended period by many scientists tackling questions about vascular and immune cell function. The culmination of this work included the demonstration by Robert Furchgott that rapid reductions in smooth muscle tone were driven by production of an endothelial cell dependent mediator. Described initially as endothelial derived relaxing factor (EDRF) [1], Salvador Moncada went on to demonstrate that EDRF was in fact identical to NO [2]. In parallel, the discovery by Ferid Murad that nitric oxide (NO) was a potent activator of soluble guanylate cyclase [3] ultimately led to the confirmation by Louis Ignarro that NO was the second messenger molecule responsible for reducing smooth muscle tone through this mechanism. This work secured Furchgott, Ignarro and Murad the Nobel 
prize for physiology or medicine in 1998 [4], an award that was built on a body of work going back many years across many disciplines.

\section{NO synthesis and actions}

$\mathrm{NO}$ is synthesised by nitric oxide synthase (NOS) from the guanidino group of arginine through oxygen and NADPH dependent oxidation producing NO, with citrulline as a by-product. Three isoforms of nitric oxide synthase regulate the production and vary in their tissue distributions. Neuronal NOS (nNOS) is predominantly found in the nervous and enteric systems but also in vascular smooth muscle [5] and cardiac myocytes [6]. Endothelial NOS (eNOS) is found predominantly in the endothelium and cardiac mycoytes [7]. The inducible isoform (iNOS) is widely expressed in response to inflammatory stress although is found constitutively at low levels in some tissues.

The actions of NO can be broadly divided into direct and indirect. Classically, NO acts as a second messenger through direct activation of soluble guanylate cyclase (sGC) resulting in increased synthesis of cyclic guanosine monophosphate (cGMP) and reduced vascular tone. In addition to the direct action on sGC, NO directly binds to heme moieties on a range of proteins and leads to a number of processes including modulation of the mitochondrial electron transport chain at the level of complex IV and inhibition of cytochrome P450-mediated metabolism.

Indirectly, NO mediates its effects through its role as a free radical. NO rapidly interacts with other free radicals such as superoxide to form secondary metabolites such as peroxynitrite $\left(\mathrm{ONOO}^{-}\right)$. Through similar reactions it can intercept lipid oxidation products (peroxy radicals) and act as chain-breaking antioxidant $[8,9]$.

The impact of the NO production in sepsis is extensive; however, the literature and in some respects its interpretation are conflicting. A detailed review of the function of $\mathrm{NO}$ is beyond the scope of this review; however, NO is essential to the maintenance of normal cardiovascular and immune responses to infection. It has diverse effects including maintenance of microvascular function, regulation of platelet aggregation and leukocyte activity, adhesion and transport [10]. Similarly, NO is directly toxic to most bacteria and has free radical scavenging action which reduces tissue injury and bioenergetic dysfunction. However, in sepsis and septic shock, these processes become dysregulated to variable degrees. Exaggerated NO production has been implicated in the development of macrovascular compromise [11], myocardial dysfunction [12], reduced responsiveness to adrenergic stimuli $[13,14]$, direct cellular toxicity and bioenergetic failure $[15,16]$. Conversely, impaired local NO production in the endothelium has been cited as a cause of the microvascular dysfunction and impaired regional perfusion seen in septic shock.

\section{Regulation of NO synthesis}

The balance of harmful and beneficial effects is determined by a series of regulatory processes that determine the site and degree of NO synthesis that arises in response to an inflammatory stimulus.

The active isoforms of NOS are homodimers and depend upon a range of co-factors for their activity. Dimerisation is essential for activation and leads to the sequestration of iron and creation of binding sites for arginine and the essential cofactor 
tetrahydrobiopterin (BH4). In addition, dimerisation facilitates electron transfer between two key domains linked by a calmodulin binding motif. In eNOS and nNOS, the binding of calmodulin to the NOS homodimer is calcium dependent. Conversely, calmodulin is tightly bound to iNOS and therefore displays calcium independent activation. Enzymatic activity also depends upon, haem, flavin mononucleotide (FMN) and flavin adenine dinucleotide (FAD) availability as well as oxygen and NADPH as cosubstrates (Fig. 1).

Differential expression of the NOS isoforms within the cell or in tissues also influences NO synthesis. eNOS is commonly found bound to caveolin, a specialised anchoring protein within the caveolae of the endothelial cell membrane [17] which may itself regulate NO production [18]. This conformation has been implicated in the development of reduced NO synthesis in the septic microvasculature. In myocytes, the three NOS isoforms are differentially distributed with eNOS predominantly found in endothelium, nNOS in the presynaptic nerves and both found in different portions of the sarcoplasmic reticulum. iNOS by contrast, when induced by pro-inflammatory stress is most commonly found in the cytoplasm where it generates a two or three log fold higher increases in NO synthesis compared to the constitutive isoforms.

\section{Therapeutic modulation of NO in sepsis}

In the years following its discovery came a burgeoning recognition that NO played an important role in the development of the vasoplegia and hypotension that is the

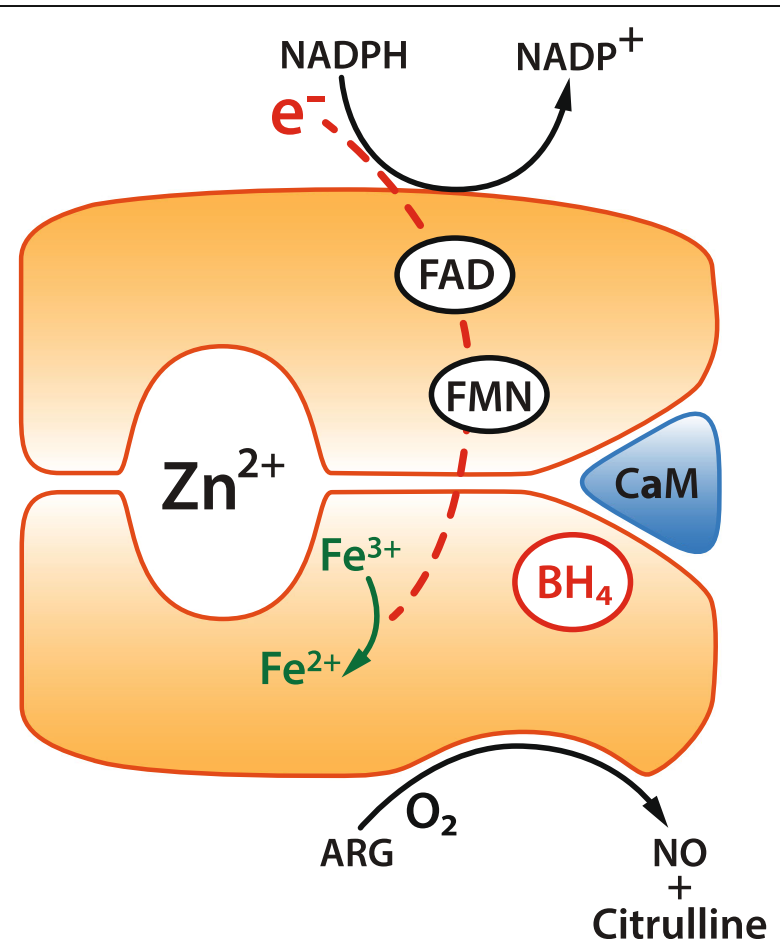

Fig. 1 Nitric oxide synthase (NOS) cofactors and activity. NOS enzymes function as homodimers within subunits structurally supported by a Zinc ion $\left(\mathrm{Zn}^{2+}\right)$. Following sequestration of iron, the binding site for arginine is expressed. Electron transfer also depends on flavin mononucleotide (FMN) and flavin adenine dinucleotide (FAD) availability and the binding of calmodulin (CaM) which is calcium dependent for eNOS and nNOS and independent for iNOS. NADPH, oxygen and tetrahydrobiopterin $(\mathrm{BH} 4)$ are essential cofactors for the synthesis of nitric oxide 
hallmark of septic shock. This led first to small scale studies of inhibition of sGC activity by methylene blue $[19,20]$, and subsequently, clinical trials of the non-specific small molecule inhibitor of all three NOS isoforms, L-NMMA. Phase II results [21] showed promise as L-NMMA demonstrated improved systemic vascular resistance and blood pressure in patients with septic shock. However, a phase III trial was terminated early due to excess mortality in the treatment group [22]. Questions regarding dose selection, blood pressure management and treatment strategy meant that interest in the area was not extinguished, and subsequent work has recognised the plethora of roles that NO has in regulating organ function in both health and disease.

In recent years, potential approaches to modulating $\mathrm{NO}$ production in sepsis have been developed targeting pathways beyond direct NOS inhibition. The remainder of this review will focus on a selection of these strategies which include modulating endogenous regulators of NOS activity, NO scavenging or donation and optimising substrate availability.

\section{Nitric oxide inhibition}

\section{Endogenous regulators of NOS activity}

Tetrahydrobiopterin (BH4) is an essential cofactor for NOS-mediated NO synthesis through facilitation of electron transfer to L-arginine. Reduced BH4 bioavailability results in the diversion of electron flow to molecular oxygen and production of free radical superoxide rather than $\mathrm{N}$ O[23], a process also known as NOS uncoupling. Reduced BH4 bioavailability has been implicated in the development of chronic cardiovascular diseases through this mechanism.

Whilst in sepsis, pro-inflammatory stress has been shown to increase production of BH4 [24], coexistent oxidative stress and reactive oxygen species cause conversion of $\mathrm{BH} 4$ to $\mathrm{BH} 2$. In addition to depleting $\mathrm{BH} 4$ scores, $\mathrm{BH} 2$ binds to NOS with equal affinity but promotes the uncoupling process [25] thereby reducing NO production. In malaria, increasing severity of disease is associated with reduced $\mathrm{BH} 4$ levels and $\mathrm{BH} 4 \mathrm{BH} 2$ ratio [26] and has been proposed as a driver of microcirculatory dysfunction in this population.

Supplementation of a $\mathrm{BH} 4$ analogue appears to reduce haemodynamic impairment, organ dysfunction and improve survival in rat models of acute inflammation and sepsis [27-29]. In an ovine model of septic shock secondary to faecal peritonitis, supplemental tetrahydrobiopterin therapy was associated with preservation of the sublingual microcirculation, reduced cardiovascular compromise and severity of lung and renal injury [30]. Furthermore, In animal models, ascorbate supplementation has been shown to restore capillary blood flow and eNOS activity in a BH4 dependent manner [31]. This has been postulated as one of the mechanisms underlying the potential benefits of Vitamin C supplementation in sepsis.

A further example of potential therapeutic approaches includes increasing the expression of endogenous inhibitors of NO synthesis. Derived from the methylation of arginine residues by the Protein Arginine Methyl Transferases (PRMTs), the methylarginines have an unusual physiological role in regulating the synthesis of NO. The three methylarginines are asymmetric dimethylarginine (ADMA), symmetric dimethyl arginine (SDMA) and, occurring at approximately a tenth of the concentration, monomethylarginine (L-NMMA). 
The asymmetric pair, ADMA and L-NMMA, acts as equipotent competitive inhibitors of arginine binding to the all three NOS isoforms. By contrast, SDMA has no direct action on NOS activity. Elevated levels of both ADMA and SDMA are associated with poor outcome in patients with sepsis; however, an increase in the ratio of ADMA to SDMA is associated with reduced mortality in patients with septic shock [32], suggesting there may be a disconnection between the association of elevated ADMA levels and the mechanisms responsible for dysregulated $\mathrm{NO}$ production.

The dominant method of methylarginine handling is enzymatic and driven by one of the two dimethylarginine dimethylaminohydroxylases (DDAH1 and DDAH2). Approximately $80 \%$ of ADMA and L-NMMA are metabolised to dimethylarginine (DMA) and L-citrulline by the DDAH isoforms, with the remaining $20 \%$ excreted by the kidney [33] (Fig. 2).

In addition to expression in the vasculature [34], DDAH1 is readily identified in the liver, kidney, brain, skeletal muscle and pancreas [35]. Small amounts of DDAH1 have also been found in the pulmonary vasculature [36] and in placental [37] tissues. The tissue distribution of DDAH2 differs markedly from that of DDAH1. Whilst both isoforms are found in blood vessels, liver and kidney, DDAH2 predominates in the placenta and is not found in the central nervous system. It is also the only isoform found in cardiomyocytes and in immune tissues [34, 35, 38]. This has led to the suggestion it may play an important role in the response to inflammatory or immune mediated conditions.

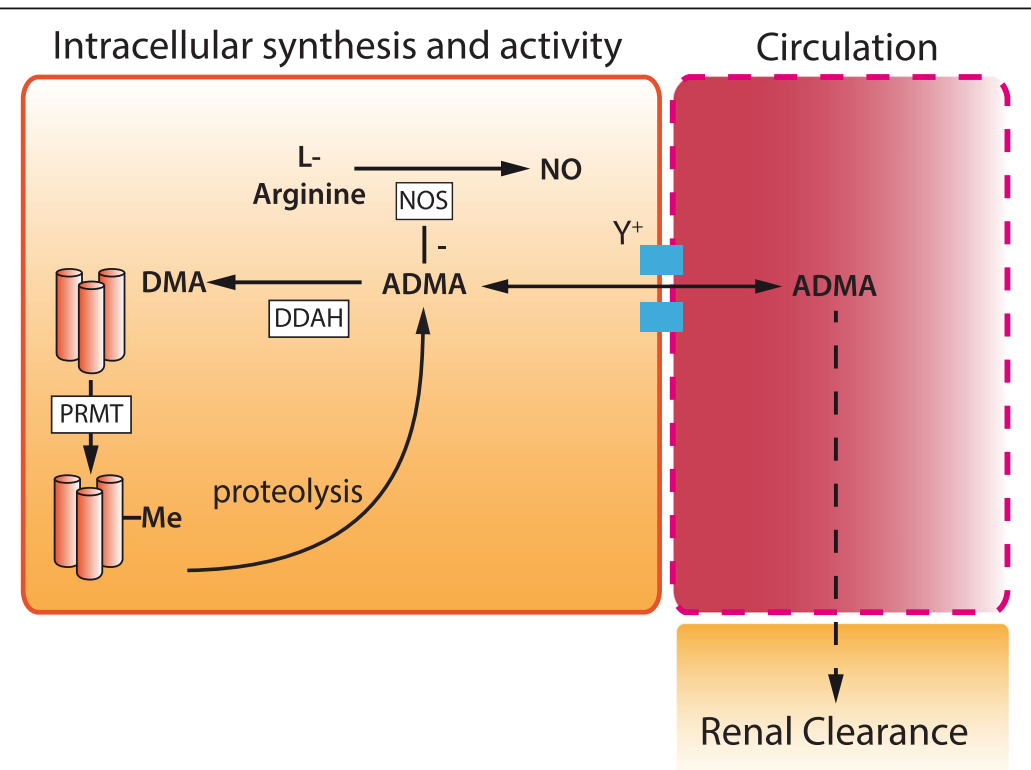

Fig. 2 Methylarginine-mediated nitric oxide synthase inhibition. Representative image of the synthesis and regulation of ADMA. Protein Arginine Methyl Transferases (PRMT) catalyse the methylation of arginine containing protein residues to ADMA and SDMA which are released upon proteolysis. ADMA and SDMA are transported via the $\mathrm{y}^{+}$cationic amino acid transporter into and out of the circulation. ADMA is metabolised by the two isoforms of dimethylarginine dimethylaminohydrolase (DDAH) in a wide range of tissues. ADMA acts intracellularly to inhibit nitric oxide synthase (NOS). ADMA is largely metabolised by DDAH to dimethylamine (DMA), a small amount is cleared unchanged through the kidney. $\mathrm{nb}$. L-NMMA (monomethylarginine) is considered to have the same synthetic pathway, activity, metabolism and clearance as ADMA but is present in only $10 \%$ of the concentration 
In rodent lipopolysaccharide (LPS) and polymicrobial models, both genetic and therapeutic inhibition of DDAH1, has been shown to offer improved survival [39]. In addition, DDAH1 inhibitor therapy was found to reduce the severity of hypotension and requirement for noradrenaline to maintain normal blood pressure. These effects still occurred when treatment was delayed until after the onset of shock symptoms. Furthermore, DDAH1 inhibition was shown to improve indices of renal and hepatic function, preserve microvascular flow and improve survival without any effect on immune cell function [39]. This favourable balance of improved vascular function without the deleterious impacts on the cardiac or immune system has led to DDAH1 inhibition being postulated as a potential therapeutic approach in septic shock.

\section{Nitric oxide scavenging}

The recognition that NO has essential functions in sepsis and that global inhibition of NO synthesis could have harmful effects, led to the hypothesis that scavenging excess NO might prove an effective therapeutic strategy [40]. One of these approaches was the development of pyridoxylated haemoglobin polyoxyethylene (PHP), which was originally developed as a candidate oxygen delivery substitute. PHP is pyridoxylated to remove its oxygen carrying capacity and then combined with polyoxyethylene to increase the apparent molecular weight of the compound. The resulting product has a high affinity for $\mathrm{NO}$ which it rapidly oxidises to the more stable nitrate as well as reducing peroxynitrite concentrations and regulating the redox state of the cell [41].

Preclinical ovine models of sepsis demonstrated that PHP improved systemic vascular resistance [42] and that treatment was not associated with impaired tissue perfusion. This led to a phase II study in of 62 patients with septic shock [43]. In this study, those treated with PHP displayed trends towards reduced requirements for vasopressors and ventilatory support. This was followed by the phase III PHOENIX study [44], which recruited 377 patients. The study showed no survival benefit following PHP therapy at 28 days but evidence of increased mortality in patients with a SOFA score of $>13$ on inclusion. Despite this, the previously observed improvements in systemic haemodynamics persisted, with survivors displaying reduced duration of vasopressor therapy. The authors concluded that regional variation in NO synthesis in the microcirculation could have been exacerbated in the PHP treated patients thereby worsening organ perfusion and accounting for the worse outcomes observed. This coupled with the inability to identify which patients had more substantially elevated systemic NO levels based on noradrenaline requirement meant that selecting patients that might benefit from this approach based on clinical indices was not possible.

\section{Increasing nitric oxide bioavailability}

\section{Substrate bioavailability}

Arginine is the substrate for NOS enzymes and its availability is a dominant factor in the regulation of NO production. Whilst most bioavailable arginine is derived from the diet, the intracellular concentrations are governed by a range of processes including transmembrane transport, enzymatic synthesis and metabolism.

In sepsis, arginine becomes a conditionally essential amino acid with reduced bioavailability resulting from a variety of factors. Exaggerated protein turnover leads to an 
increase in stored arginine release however in patients with sepsis, reduced dietary intake of arginine and citrulline $[45,46]$ is coupled with increased turnover by NOS and arginase enzymes [47]. This coupled with reduced de novo synthesis at the tissue level in organ failure [48] means that circulating arginine concentrations are substantially reduced regardless of the infectious cause [49-51] with direct consequences for the production of $\mathrm{NO}$ and the microcirculation [52]

Extensive investigation has been undertaken exploring the potential role of exogenous arginine supplementation in sepsis. A number of animal models have produced promising results with a murine [52] and pretreatment porcine inflammatory model [53] showing improved microvascular function and organ perfusion mediated by increased NO production. In healthy volunteers, arginine supplementation is well tolerated at doses less than 8g/day; however, supplementation at doses above this was associated with gastrointestinal side effects [54]. In patients with critical illness, arginine supplementation has not consistently demonstrated clinically relevant improvements in outcome. There is some trial evidence suggesting supplementing arginine in addition to other nutrients may result in a reduced hospital length of stay [55] or improved organ function [56]. Preiser et al. [57] successfully increased plasma arginine concentrations via enteral supplementation in a small randomised controlled trial of a mixed ICU population. Whilst this was associated with some signal of increased arginase activity, no increase in plasma markers of NO production was detected. In a subsequent randomised trial of 597 critically ill patients, an immunonutrition approach including supplementation of arginine as well as glutamine and omega-3 was not associated with improved clinical outcomes [58]. A further study of arginine containing enteral immunonutrition versus parenteral therapy was stopped after an interim analysis suggested an excess mortality in patients receiving enteral supplementation [59]. This has led to the recommendation in the surviving sepsis guidelines that arginine supplementation is not used to treat patients with sepsis [60].

In addition to dietary uptake, arginine can be synthesised through the conversion of citrulline by a pair of enzymes that are found in the cytosol, argininosuccinate synthetase (ASS) and argininosuccinate lyase (ASL) [61] (Fig. 3). The majority of bioavailable citrulline is synthesised by enterocytes with some derived from the diet [62] and a small proportion synthesised in the kidney, liver and enterocytes from ornithine by ornithine transcarbamoylase [63]. Citrulline bioavailability is also reduced in sepsis. Observed in patient populations to be associated with increased mortality [64], a low citrulline concentration is likely multifactorial. In addition to reduced dietary intake, reduced uptake of the citrulline precursor glutamine from the gut may play a role [65]. Compensatory increases in the expression of ornithine transcarbamoylase which synthesises citrulline from ornithine in the kidney may mitigate this effect to some degree [66].

A number of cell types use citrulline conversion by ASS and ASL to generate endogenous arginine. These include vascular smooth muscle [67], macrophages [68], neural cells [69] and endothelial cells [70, 71]. Importantly, in endothelial cells, ASS and ASL co-locate with eNOS and play an important role in regulating endogenous NO synthesis [72].

In sepsis, ASS expression is elevated in both the vasculature and immune cell populations, possibly in order to facilitate local NO production by iNOS [73, 74]. In animal models, heterozygote and tissue specific knockout of ASS are associated with worse 


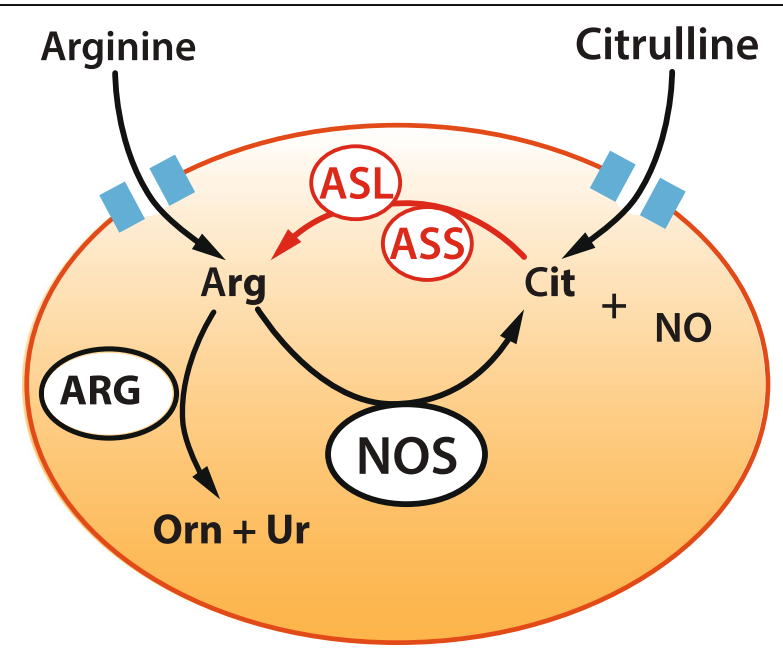

Fig. 3 Arginine bioavailability. Arginine (ARG) is transported into the cell via cationic amino acid transporters and is converted to citrulline (Cit) and NO. Citrulline derived from a number of sources including diet can be converted to arginine by argininosuccinate synthetase (ASS) and argininosuccinate lyase (ASL) increasing the available intracellular arginine. Arginase (ARG) metabolises arginine to ornithine (Orn) and urea (Ur)

outcomes due to reduced immune cell NO synthesis [75]. Supplementation with recombinant ASS mitigates the lethal effects of LPS in animal models although the mechanism of efficacy may also be related to direct binding to Gram negative bacteria reducing organism pathogenicity rather than the production of increased arginine [74].

With the similar aim of augmenting arginine and subsequent $\mathrm{NO}$ bioavailability and with some evidence from animal models [52], citrulline supplementation has also been proposed as a possible treatment strategy in sepsis. Whilst there is some evidence of association between low citrulline concentrations and the development of ARDS [46] and gut mucosal integrity in patients with sepsis [76], there is no prospective evidence to recommend citrulline supplementation at this stage.

The isoforms of the arginase enzymes degrade arginine to ornithine and urea rendering it an important regulator substrate availability and therefore of NO synthesis in the cell (Fig. 3). The arginase isoforms have differing tissue distributions, with arginase 1 expressed in endothelial cells, immune cells and the liver. Arginase 2 is also found in the endothelium [77] and immune cells [78] but is also detected in the kidney, brain and small intestine.

The expression of arginase isoforms during sepsis is a dynamic process that points to a role in regulating the initiation and resolution of inflammation [79-81] by limiting arginine availability. After an acute inflammatory stress, arginase induction typically arises some hours after peak iNOS induction [45]. This is responsible in part for the downregulation of $\mathrm{NO}$ synthesis and is best characterised in immune cells where it defines the transition of the macrophage from the pro-inflammatory M1 to the restorative M2 phenotype where arginase mediates the synthesis of proline and polyamines crucial to the process of wound healing [82].

Arginase 1 knockout immune cells and mice deficient in arginase 1 in endothelial and haematopoietic cells are prone to exaggerated NO synthesis in LPS models of inflammation with an associated microvascular dysfunction seen in murine models [83]. In patients, limited data suggests that levels of the enzyme in the circulation are 
elevated in sepsis but is not directly related to clinical indices of illness severity [84]. Although no therapeutic evaluation of arginase modulation is underway, the role of the enzymes in regulating systemic and local arginine concentrations is undoubtedly important and further understanding of the balance between NOS and arginase expression may yield novel therapeutic approaches.

\section{Targeting microcirculatory dysfunction}

The wide recognition of the importance of $\mathrm{NO}$ in maintaining the microcirculation, combined with the negative outcomes of trials of NOS inhibition has also led to suggestions that rather than reducing synthesis of $\mathrm{NO}$, attention should focus on the use of $\mathrm{NO}$ donors to improve microvascular function, reduce shunting and optimise tissue perfusion in septic shock. Two distinct approaches have been proposed. The first involves optimising eNOS activity within the vascular endothelium which, as described above, is known to be impaired in sepsis due to the uncoupling of $\mathrm{NO}$ production due in part to reduced $\mathrm{BH} 4$ availability, lack of availability of substrate and elevated oxidative stress.

The alternative therapeutic strategy is to deliver exogenous compounds which can release $\mathrm{NO}$ at the microcirculatory level in order to optimise small vessel function. There are a number of proposed functions of the microcirculation that could be improved through NO modulation which include smooth muscle relaxation, reduced platelet aggregation and microthrombus formation and reduced endothelial leak and interstitial oedema. In addition, there is evidence that inorganic nitrites may offer some protection from ischaemia reperfusion injury and have a cardioprotective effect through a range of actions on mitochondrial and cellular function $[85,86]$.

This approach was tested in a small study of 8 patients as early as 2002 with nitroglycerin infusion which led to reported improvements in the sublingual microcirculation [87] although a subsequent randomised controlled trial published in 2010 randomised 70 patients to receive nitroglycerin infusion or placebo and found that this was not associated with improved microvascular flow in any category of vessel or interestingly on systemic haemodynamics, suggesting that it may not have been having the desired pharmacodynamic effect [88]. One potential reason for this could be the failure to effectively convert nitroglycerin to $\mathrm{NO}$ in vivo due to dysfunction of aldehyde dehydrogenase type 2 in capacitance vessels, which may not function effectively in patients with sepsis and leads to reduced nitroglycerin bioactivation [89]. This however remains only one endogenous route of activation [90] and therefore may not entirely explain this apparent result.

Based on a similar methodological approach, the direct administration of $\mathrm{NO}$ via an inhaled route has recently been trialled in patients with sepsis [91]. In a randomised trial of 50 patients, direct $\mathrm{NO}$ administration was able to increase circulating nitrite levels consistent with the hypothesis that pulmonary delivery of NO could lead to increased systemic availability; however, no impact on sublingual microvascular or organ function was detected.

\section{Conclusions}

Extensive research has led to the recognition that $\mathrm{NO}$ synthesis is regulated by a range of mechanisms which determine the production and actions of NO. Substrate and co- 
factor availability all contribute to NOS activity, which also determined on a tissue level by protein expression, cellular localisation and the presence of endogenous regulators.

In the last decade therapeutic research into the modulation of $\mathrm{NO}$ in critical illness has taken on a Janusian quality as it explores the competing challenges of overproduction of NO in some systems and impaired synthesis in others. Exaggerated NO production is responsible for cardiac, macrovascular and cellular dysfunction; however, microvascular function due to reduced eNOS activity and NO synthesis also appears to play an important role in outcome. The development of novel treatments in this area must mitigate the pathological consequences of at least one of these without exacerbating the other or impairing the essential physiological NO synthesis that is core to the response to infection. This challenge must be addressed if an improved understanding of the mechanistic role of $\mathrm{NO}$ in sepsis can be translated into therapies that improve outcomes for patients.

\section{Abbreviations}

ADMA: Asymmetric dimethylarginine; ASL: Arginosuccinate lyase; ASS: Arginosuccinate synthetase; BH4: Tetrahydrobiopterin; cGMP: Cyclic guanosine monophosphate; DDAH: Dimethylaminohydroxylases; DMA: Dimethylarginine; EDRF: Endothelial derived relaxing factor; FAD: Flavin adenine dinucleotide; FMN: Flavin mononucleotide; L-NMMA: Monomethylarginine; LPS: Lipopolysaccharide; NO: Nitric oxide; NOS: Nitric oxide synthase; PHP: Pyridoxylated haemoglobin polyoxyethylene; PRMTs: Protein Arginine Methyl Transferases; RNS: Reactive nitrogen species; SDMA: Symmetric dimethyl arginine; sGC: Soluble guanylate cyclase; SOFA: Sequential Organ Failure Assessment

Acknowledgements

None

Authors' contributions

SL was the sole contributor to this work. The author read and approved the final manuscript.

Authors' information

$\mathrm{SL}$ is a clinician specialising in anaesthesia and intensive care medicine. His research is focussed on translational studies exploring the mechanisms of vascular dysfunction in sepsis.

Funding

SL is funded by a NIHR Clinical Lecturer post at Cambridge University

Availability of data and materials

Not applicable

Ethics approval and consent to participate

Not applicable

Consent for publication

Not applicable

Competing interests

$\mathrm{SL}$ is a founding director of Critical Pressure Ltd, a biotechnology company developing small molecule modulators of vascular nitric oxide synthesis.

Received: 26 August 2019 Accepted: 11 October 2019

Published online: 02 December 2019

References

1. Furchgott RF, Zawadzki JV (1980) The obligatory role of endothelial cells in the relaxation of arterial smooth muscle by acetylcholine. Nature. 288:373-376. https://doi.org/10.1038/288373a0

2. Palmer RM, Ferrige AG, Moncada S (1987) Nitric oxide release accounts for the biological activity of endotheliumderived relaxing factor. Nature. 327:524-526. https://doi.org/10.1038/327524a0

3. Murad F (1986) Cyclic guanosine monophosphate as a mediator of vasodilation. J Clin Invest 78:1-5. https://doi.org/10. 1172/jci112536

4. Smith O (1998) Nobel Prize for NO research. Nat Med 4:1215. https://doi.org/10.1038/3182

5. Ward ME, Toporsian M, Scott JA, Teoh H, Govindaraju V, Quan A, Wener AD, Wang G, Bevan SC, Newton DC, Marsden PA (2005) Hypoxia induces a functionally significant and translationally efficient neuronal NO synthase mRNA variant. J Clin Invest 115:3128-3139. https://doi.org/10.1172/JCI20806 
6. Xu KY, Huso DL, Dawson TM, Bredt DS, Becker LC (1999) Nitric oxide synthase in cardiac sarcoplasmic reticulum. Proc Natl Acad Sci 96:657-662. https://doi.org/10.1073/pnas.96.2.657

7. Massion PB, Feron O, Dessy C, Balligand JL (2003) Nitric oxide and cardiac function: ten years after, and continuing. Circ Res 93:388-398. https://doi.org/10.1161/01.res.0000088351.58510.21

8. Thomas DD, Ridnour LA, Isenberg JS, Flores-Santana W, Switzer CH, Donzelli S, Hussain P, Vecoli C, Paolocci N, Ambs S, Colton CA, Harris CC, Roberts DD, Wink DA (2008) The chemical biology of nitric oxide: implications in cellular signaling. Free Radic Biol Med 45:18-31. https://doi.org/10.1016/j.freeradbiomed.2008.03.020

9. Radi R (2018) Oxygen radicals, nitric oxide, and peroxynitrite: redox pathways in molecular medicine. Proc Natl Acad Sci 115:5839-5848. https://doi.org/10.1073/pnas.1804932115

10. Loughran, P.A., Z. Lei, L. Xu, M. Deng, and T.R. Billiar, Chapter 22 - Nitric oxide in sepsis and hemorrhagic shock: beneficial or detrimental?, in Nitric oxide (Third Edition), L.J. Ignarro and B.A. Freeman, Editors. 2017, Academic Press. p. 289-300.

11. Cauwels A (2007) Nitric oxide in shock. Kidney Int 72:557-565. https://doi.org/10.1038/sj.ki.5002340

12. Antonucci E, Fiaccadori E, Donadello K, Taccone FS, Franchi F, Scolletta S (2014) Myocardial depression in sepsis: from pathogenesis to clinical manifestations and treatment. J Crit Care 29:500-511. https://doi.org/10.1016/j.jcrc.2014.03.028

13. Tsuneyoshi I, Kanmura Y, Yoshimura N (1996) Nitric oxide as a mediator of reduced arterial responsiveness in septic patients. Crit Care Med 24:1083-1086. https://doi.org/10.1097/00003246-199606000-00033

14. Levy B, Collin S, Sennoun N, Ducrocq N, Kimmoun A, Asfar P, Perez P, Meziani F (2010) Vascular hyporesponsiveness to vasopressors in septic shock: from bench to bedside. Intensive Care Med 36:2019-2029. https://doi.org/10.1007/s00134010-2045-8

15. Brealey D, Brand M, Hargreaves I, Heales S, Land J, Smolenski R, Davies N, Cooper C, Singer M (2002) Association between mitochondrial dysfunction and severity and outcome of septic shock. Lancet. 360:219-223

16. Dyson A, Bryan NS, Fernandez BO, Garcia-Saura MF, Saijo F, Mongardon N, Rodriguez J, Singer M, Feelisch M (2011) An integrated approach to assessing nitroso-redox balance in systemic inflammation. Free Radic Biol Med 51:1137-1145. https://doi.org/10.1016/j.freeradbiomed.2011.06.012

17. Feron O, Belhassen L, Kobzik L, Smith TW, Kelly RA, Michel T (1996) Endothelial Nitric Oxide Synthase Targeting to Caveolae: SPECIFIC INTERACTIONS WITH CAVEOLIN ISOFORMS IN CARDIAC MYOCYTES AND ENDOTHELIAL CELLS. J Biol Chem 271:22810-22814. https://doi.org/10.1074/jbc.271.37.22810

18. Kone BC, Kuncewicz T, Zhang W, Yu ZY (2003) Protein interactions with nitric oxide synthases: controlling the right time, the right place, and the right amount of nitric oxide. Am J Physiol Ren Physiol 285:F178-F190. https://doi.org/10.1152/ ajprenal.00048.2003

19. Kirov MY, Evgenov OV, Evgenov NV, Egorina EM, Sovershaev MA, Sveinbjornsson B, Nedashkovsky EV, Bjertnaes LJ (2001) Infusion of methylene blue in human septic shock: a pilot, randomized, controlled study. Crit Care Med 29:1860-1867

20. Andresen, M., A. Dougnac, O. Diaz, G. Hernandez, L. Castillo, G. Bugedo, M. Alvarez, and J. Dagnino (1998) Use of methylene blue in patients with refractory septic shock: impact on hemodynamics and gas exchange. Journal of Critical Care. 13:164-168.DOl: https://doi.org/10.1016/S0883-9441(98)90001-6

21. Bakker, J., R. Grover, A. McLuckie, L. Holzapfel, J. Andersson, R. Lodato, D. Watson, S. Grossman, J. Donaldson, J. Takala, and o.b.o.t.G.W.IS.S.S. Group (2004) Administration of the nitric oxide synthase inhibitor NG-methyl--arginine hydrochloride (546C88) by intravenous infusion for up to 72 hours can promote the resolution of shock in patients with severe sepsis: Results of a randomized, double-blind, placebo-controlled multicenter study (study no. 144-002)*. Critical Care Medicine. 32:1-12.DOI: 10.1097/01.ccm.0000105118.66983.19

22. Lopez A, Lorente JA, Steingrub J, Bakker J, McLuckie A, Willatts S, Brockway M, Anzueto A, Holzapfel L, Breen D, Silverman MS, Takala J, Donaldson J, Arneson C, Grove G, Grossman S, Grover R (2004) Multiple-center, randomized, placebo-controlled, double-blind study of the nitric oxide synthase inhibitor 546C88: effect on survival in patients with septic shock. Crit Care Med 32:21-30. https://doi.org/10.1097/01.CCM.0000105581.01815.C6

23. Yuyun MF, Ng LL, Ng GA (2018) Endothelial dysfunction, endothelial nitric oxide bioavailability, tetrahydrobiopterin, and 5-methyltetrahydrofolate in cardiovascular disease. Where are we with therapy? Microvasc Res 119:7-12. https://doi.org/ 10.1016/j.mvr.2018.03.012

24. Werner ER, Werner-Felmayer G, Mayer B (1998) Tetrahydrobiopterin, cytokines, and nitric oxide synthesis. Proc Soc Exp Biol Med 219:171-182

25. Hye-Lim, K, amp, amp, and P. Young Shik (2010) Maintenance of cellular tetrahydrobiopterin homeostasis. BMB Rep 43:584-592

26. Yeo TW, Lampah DA, Kenangalem E, Tjitra E, Price RN, Weinberg JB, Hyland K, Granger DL, Anstey NM (2015) Impaired systemic tetrahydrobiopterin bioavailability and increased dihydrobiopterin in adult falciparum malaria: association with disease severity, impaired microvascular function and increased endothelial activation. PLoS Pathog 11:e1004667. https://doi.org/10.1371/journal.ppat.1004667

27. Fitzal F, Redl H, Strohmaier W, Werner ER, Bahrami S (2002) A 4-amino analogue of tetrahydrobiopterin attenuates endotoxin-induced hemodynamic alterations and organ injury in rats. Shock. 18:158-162

28. Bahrami S, Fitzal F, Peichl G, Gasser H, Fuerst W, Banerjee A, Strohmaier W, Redl H, Werner-Felmayer G, Werner ER (2000) Protection against endotoxemia in rats by a novel tetrahydrobiopterin analogue. Shock. 13: 386-391

29. Dumbarton TC, Maxan A, Farah N, Sharawy N, Zhou J, Nantais J, Lehmann C (2017) Tetrahydrobiopterin improves microcirculation in experimental sepsis. Clin Hemorheol Microcirc 67:15-24. https://doi.org/10.3233/ch-160207

30. He X, Su F, Velissaris D, Salgado DR, de Souza Barros D, Lorent S, Taccone FS, Vincent JL, De Backer D (2012) Administration of tetrahydrobiopterin improves the microcirculation and outcome in an ovine model of septic shock. Crit Care Med 40:2833-2840. https://doi.org/10.1097/CCM.0b013e31825b88ba

31. Tyml K, Li F, Wilson JX (2008) Septic impairment of capillary blood flow requires nicotinamide adenine dinucleotide phosphate oxidase but not nitric oxide synthase and is rapidly reversed by ascorbate through an endothelial nitric oxide synthase-dependent mechanism. Crit Care Med 36:2355-2362. https:/doi.org/10.1097/ CCM.0b013e31818024f6

32. Lambden S, Tomlinson J, Piper S, Gordon AC, Leiper J (2018) Evidence for a protective role for the rs805305 single nucleotide polymorphism of dimethylarginine dimethylaminohydrolase 2 (DDAH2) in septic shock through the regulation of DDAH activity. Crit Care 22:336. https://doi.org/10.1186/s13054-018-2277-5 
33. Tran, C.T.L., J.M. Leiper, and P. Vallance (2003) The DDAH/ADMA/NOS pathway. Atherosclerosis Supplements. 4:33-40. DOI: https://doi.org/10.1016/S1567-5688(03)00032-1

34. Tran CT, Fox MF, Vallance P, Leiper JM (2000) Chromosomal localization, gene structure, and expression pattern of DDAH1: comparison with DDAH2 and implications for evolutionary origins. Genomics. 68:101-105. https://doi.org/10. 1006/geno.2000.6262

35. Leiper JM (1999) Identification of two human dimethylarginine dimethylaminohydrolases with distinct tissue distributions and homology with microbial arginine deiminases. Biochem.J. 343:209-214

36. Lucio lannone LZ, Dubois O, Duluc L, Rhodes CJ, Wharton J, Wilkins MR, Leiper J, Wojciak-Stothard B (2014) miR-21/DDAH1 pathway regulates pulmonary vascular responses to hypoxia. Biochem J 462:103-112. https://doi.org/10.1042/BJ20140486

37. Anderssohn M, Maass LM, Diemert A, Luneburg N, Atzler D, Hecher K, Boger RH (2012) Severely decreased activity of placental dimethylarginine dimethylaminohydrolase in pre-eclampsia. Eur J Obstet Gynecol Reprod Biol 161:152-156. https://doi.org/10.1016/j.ejogrb.2011.12.032

38. Lambden S, Kelly P, Ahmetaj-Shala B, Wang Z, Lee B, Nandi M, Torondel B, Delahaye M, Dowsett L, Piper S, Tomlinson J, Caplin B, Colman L, Boruc O, Slaviero A, Zhao L, Oliver E, Khadayate S, Singer M, Arrigoni F, Leiper J (2015) Dimethylarginine dimethylaminohydrolase 2 regulates nitric oxide synthesis and hemodynamics and determines outcome in polymicrobial sepsis. Arterioscler Thromb Vasc Biol 35:1382-1392. https://doi.org/10.1161/atvbaha.115.305278

39. Wang Z, Lambden S, Taylor V, Sujkovic E, Nandi M, Tomlinson J, Dyson A, McDonald N, Caddick S, Singer M, Leiper J (2014) Pharmacological inhibition of DDAH1 improves survival, hemodynamics and organ function in experimental septic shock. Biochem J 460:309-316. https://doi.org/10.1042/BJ20131666

40. Harbrecht BG (2006) Therapeutic use of nitric oxide scavengers in shock and sepsis. Curr Pharm Des 12:3543-3549. https://doi.org/10.2174/138161206778343000

41. Privalle, C., T. Talarico, T. Keng, and J. DeAngelo (2000) Pyridoxalated hemoglobin polyoxyethylene: a nitric oxide scavenger with antioxidant activity for the treatment of nitric oxide-induced shock. Free Radical Biology and Medicine. 28:1507-1517.DOl: https://doi.org/10.1016/S0891-5849(00)00260-4

42. Bone HG, Schenarts PJ, Fischer SR, McGuire R, Traber LD, Traber DL (1998) Pyridoxalated hemoglobin polyoxyethylene conjugate reverses hyperdynamic circulation in septic sheep. J Appl Physiol 84:1991-1999. https://doi.org/10.1152/jappl. 1998.84.6.1991

43. Kinasewitz GT, Privalle CT, Imm A, Steingrub JS, Malcynski JT, Balk RA, DeAngelo J (2008) Multicenter, randomized, placebo-controlled study of the nitric oxide scavenger pyridoxalated hemoglobin polyoxyethylene in distributive shock*. Crit Care Med 36:1999-2007. https://doi.org/10.1097/CCM.0b013e31817bfe84

44. Vincent J-L, Privalle CT, Singer M, Lorente JA, Boehm E, Meier-Hellmann A, Darius H, Ferrer R, Sirvent J-M, Marx G (2015) Multicenter, randomized, placebo-controlled phase III study of pyridoxalated hemoglobin polyoxyethylene in distributive shock (PHOENIX). Crit Care Med 43:57-64

45. Bansal V, Ochoa JB (2003) Arginine availability, arginase, and the immune response. Curr Opin Clin Nutr Metab Care 6: 223-228. https://doi.org/10.1097/01.mco.0000058594.27240.12

46. Ware LB, Magarik JA, Wickersham N, Cunningham G, Rice TW, Christman BW, Wheeler AP, Bernard GR, Summar ML (2013) Low plasma citrulline levels are associated with acute respiratory distress syndrome in patients with severe sepsis. Crit Care 17:R10. https://doi.org/10.1186/cc11934

47. Durante W, Johnson FK, Johnson RA (2007) Arginase: a critical regulator of nitric oxide synthesis and vascular function. Clin Exp Pharmacol Physiol 34:906-911. https://doi.org/10.1111/j.1440-1681.2007.04638.x

48. Lau T, Owen W, Yu YM, Noviski N, Lyons J, Zurakowski D, Tsay R, Ajami A, Young VR, Castillo L (2000) Arginine, citrulline, and nitric oxide metabolism in end-stage renal disease patients. J Clin Invest 105:1217-1225. https://doi.org/10.1172/jci7199

49. Davis JS, Anstey NM (2011) Is plasma arginine concentration decreased in patients with sepsis? A systematic review and meta-analysis. Crit Care Med 39:380-385. https://doi.org/10.1097/CCM.0b013e3181ffdgf7

50. Luiking YC, Poeze M, Ramsay G, Deutz NE (2009) Reduced citrulline production in sepsis is related to diminished de novo arginine and nitric oxide production. Am J Clin Nutr 89:142-152. https://doi.org/10.3945/ajcn.2007.25765

51. Kao CC, Bandi V, Guntupalli KK, Wu M, Castillo L, Jahoor F (2009) Arginine, citrulline and nitric oxide metabolism in sepsis. Clin Sci (Lond) 117:23-30. https://doi.org/10.1042/cs20080444

52. Wijnands KA, Vink H, Briede JJ, van Faassen EE, Lamers WH, Buurman WA, Poeze M (2012) Citrulline a more suitable substrate than arginine to restore NO production and the microcirculation during endotoxemia. PLoS One 7:e37439. https://doi.org/10.1371/journal.pone.0037439

53. Poeze M, Bruins MJ, Kessels F, Luiking YC, Lamers WH, Deutz NE (2011) Effects of L-arginine pretreatment on nitric oxide metabolism and hepatosplanchnic perfusion during porcine endotoxemia. Am J Clin Nutr 93:1237-1247. https://doi.org/ 10.3945/ajcn.110.007237

54. Boger RH (2014) The pharmacodynamics of L-arginine. Altern Ther Health Med 20:48-54

55. Bower RH, Cerra FB, Bershadsky B, Licari JJ, Hoyt DB, Jensen GL, Van Buren CT, Rothkopf MM, Daly JM, Adelsberg BR (1995) Early enteral administration of a formula (Impact) supplemented with arginine, nucleotides, and fish oil in intensive care unit patients: results of a multicenter, prospective, randomized, clinical trial. Crit Care Med 23:436-449

56. Beale RJ, Sherry T, Lei K, Campbell-Stephen L, McCook J, Smith J, Venetz W, Alteheld B, Stehle P, Schneider H (2008) Early enteral supplementation with key pharmaconutrients improves Sequential Organ Failure Assessment score in critically ill patients with sepsis: outcome of a randomized, controlled, double-blind trial. Crit Care Med 36:131-144

57. Preiser JC, Berre PJ, Van Gossum A, Cynober L, Vray B, Carpentier Y, Vincent JL (2001) Metabolic effects of arginine addition to the enteral feeding of critically ill patients. JPEN J Parenter Enteral Nutr 25:182-187. https://doi.org/10.1177/ 0148607101025004182

58. Kieft H, Roos AN, van Drunen JD, Bindels AJ, Bindels JG, Hofman Z (2005) Clinical outcome of immunonutrition in a heterogeneous intensive care population. Intensive Care Med 31:524-532. https://doi.org/10.1007/s00134-005-2564-x

59. Bertolini G, lapichino G, Radrizzani D, Facchini R, Simini B, Bruzzone P, Zanforlin G, Tognoni G (2003) Early enteral immunonutrition in patients with severe sepsis: results of an interim analysis of a randomized multicentre clinical trial. Intensive Care Med 29:834-840. https://doi.org/10.1007/s00134-003-1711-5

60. Rhodes, A., L.E. Evans, W. Alhazzani, M.M. Levy, M. Antonelli, R. Ferrer, A. Kumar, J.E. Sevransky, C.L. Sprung, M.E. Nunnally, B. Rochwerg, G.D. Rubenfeld, D.C. Angus, D. Annane, R.J. Beale, G.J. Bellinghan, G.R. Bernard, J.-D. Chiche, C. Coopersmith, 
D.P. De Backer, CJ. French, S. Fujishima, H. Gerlach, J.L. Hidalgo, S.M. Hollenberg, A.E. Jones, D.R. Karnad, R.M. Kleinpell, Y. Koh, T.C. Lisboa, F.R. Machado, J. Marini, J.C. Marshall, J.E. Mazuski, L.A. McIntyre, A.S. McLean, S. Mehta, R.P. Moreno, J. Myburgh, P. Navalesi, O. Nishida, T.M. Osborn, A. Perner, C.M. Plunkett, M. Ranieri, C.A. Schorr, M.A. Seckel, C.W. Seymour, L. Shieh, K.A. Shukri, S.Q. Simpson, M. Singer, B.T. Thompson, S.R. Townsend, T. Van der Poll, J.-L. Vincent, W.J. Wiersinga, J.L. Zimmerman, and R.P. Dellinger (2017) Surviving sepsis campaign: international guidelines for management of sepsis and septic shock: 2016. Intensive Care Medicine:1-74.DOI: https://doi.org/10.1007/s00134-017-4683-6

61. Dhanakoti SN, Brosnan JT, Herzberg GR, Brosnan ME (1990) Renal arginine synthesis: studies in vitro and in vivo. Am J Phys 259:E437-E442. https://doi.org/10.1152/ajpendo.1990.259.3.E437

62. van de Poll MC, Ligthart-Melis GC, Boelens PG, Deutz NE, van Leeuwen PA, Dejong CH (2007) Intestinal and hepatic metabolism of glutamine and citrulline in humans. J Physiol 581:819-827. https://doi.org/10.1113/jphysiol.2006.126029

63. Marini JC (2012) Arginine and ornithine are the main precursors for citrulline synthesis in mice. J Nutr 142:572-580. https://doi.org/10.3945/jn.111.153825

64. Galban C, Montejo JC, Mesejo A, Marco P, Celaya S, Sanchez-Segura JM, Farre M, Bryg DJ (2000) An immune-enhancing enteral diet reduces mortality rate and episodes of bacteremia in septic intensive care unit patients. Crit Care Med 28: 643-648. https://doi.org/10.1097/00003246-200003000-00007

65. Kao C, Hsu J, Bandi V, Jahoor F (2013) Alterations in glutamine metabolism and its conversion to citrulline in sepsis. Am J Physiol Endocrinol Metab 304:E1359-E1364. https://doi.org/10.1152/ajpendo.00628.2012

66. Cynober L, Moinard C, De Bandt JP (2010) The 2009 ESPEN Sir David Cuthbertson. Citrulline: a new major signaling molecule or just another player in the pharmaconutrition game? Clin Nutr 29:545-551. https://doi.org/10.1016/j.clnu. 2010.07.006

67. Wileman SM, Mann GE, Pearson JD, Baydoun AR (2003) Role of L-citrulline transport in nitric oxide synthesis in rat aortic smooth muscle cells activated with LPS and interferon-gamma. Br J Pharmacol 140:179-185. https://doi.org/10.1038/sj. bjp.0705407

68. Nussler AK, Billiar TR, Liu ZZ, Morris SM Jr (1994) Coinduction of nitric oxide synthase and argininosuccinate synthetase in a murine macrophage cell line. Implications for regulation of nitric oxide production. J Biol Chem 269:1257-1261

69. Schmidlin A, Fischer S, Wiesinger H (2000) Transport of L-citrulline in neural cell cultures. Dev Neurosci 22:393-398. https://doi.org/10.1159/000017468

70. Goodwin BL, Solomonson LP, Eichler DC (2004) Argininosuccinate synthase expression is required to maintain nitric oxide production and cell viability in aortic endothelial cells. J Biol Chem 279:18353-18360. https://doi.org/10.1074/jbc M308160200

71. Hilderman RH, Casey TE, Pojoga LH (2000) P(1),P(4)-Diadenosine 5'-tetraphosphate modulates I-arginine and I-citrulline uptake by bovine aortic endothelial cells. Arch Biochem Biophys 375:124-130. https://doi.org/10.1006/abbi.1999.1643

72. Flam BR, Eichler DC, Solomonson LP (2007) Endothelial nitric oxide production is tightly coupled to the citrulline-NO cycle. Nitric Oxide 17:115-121. https://doi.org/10.1016/j.niox.2007.07.001

73. Kawahara K, Gotoh T, Oyadomari S, Kajizono M, Kuniyasu A, Ohsawa K, Imai Y, Kohsaka S, Nakayama H, Mori M (2001) Co-induction of argininosuccinate synthetase, cationic amino acid transporter-2, and nitric oxide synthase in activated murine microglial cells. Brain Res Mol Brain Res 90:165-173

74. Prima V, Wang A, Molina G, Wang KK, Svetlov SI (2011) Inhibition of LPS toxicity by hepatic argininosuccinate synthase (ASS): novel roles for ASS in innate immune responses to bacterial infection. Int Immunopharmacol 11:1180-1188. https://doi.org/10.1016/j.intimp.2011.03.016

75. Wijnands KA, Castermans TM, Hommen MP, Meesters DM, Poeze M (2015) Arginine and citrulline and the immune response in sepsis. Nutrients. 7:1426-1463. https://doi.org/10.3390/nu7031426

76. Crenn, P., N. Neveux, S. Chevret, P. Jaffray, L. Cynober, J.-C. Melchior, and D. Annane (2014) Plasma I-citrulline concentrations and its relationship with inflammation at the onset of septic shock: a pilot study. Journal of Critical Care. 29:315.e1-315.e6.DOl: https://doi.org/10.1016/j.jcrc.2013.11.015

77. Buga GM, Singh R, Pervin S, Rogers NE, Schmitz DA, Jenkinson CP, Cederbaum SD, Ignarro $L$ (1996) Arginase activity in endothelial cells: inhibition by NG-hydroxy-L-arginine during high-output NO production. Am J Phys Heart Circ Phys 271:H1988-H1998. https://doi.org/10.1152/ajpheart.1996.271.5.H1988

78. Morris SM Jr, Kepka-Lenhart D, Chen L-C (1998) Differential regulation of arginases and inducible nitric oxide synthase in murine macrophage cells. American Journal of Physiology-Endocrinology and Metabolism 275:E740-E747. https://doi. org/10.1152/ajpendo.1998.275.5.E740

79. Yang Z, Ming X-F (2014) Functions of arginase isoforms in macrophage inflammatory responses: impact on cardiovascular diseases and metabolic disorders. Front Immunol 5:533. https://doi.org/10.3389/fimmu.2014.00533

80. Cowburn AS, Crosby A, Macias D, Branco C, Colaço RDDR, Southwood M, Toshner M, Crotty Alexander LE, Morrell NW, Chilvers ER, Johnson RS (2016) HIF2a-arginase axis is essential for the development of pulmonary hypertension. Proc Natl Acad Sci 113:8801-8806. https://doi.org/10.1073/pnas.1602978113

81. Louis CA, Reichner JS, Henry WL Jr, Mastrofrancesco B, Gotoh T, Mori M, Albina JE (1998) Distinct arginase isoforms expressed in primary and transformed macrophages: regulation by oxygen tension. Am J Phys 274:R775-R782. https:// doi.org/10.1152/ajpregu.1998.274.3.R775

82. Rath M, Müller I, Kropf P, Closs El, Munder M (2014) Metabolism via Arginase or Nitric Oxide Synthase: Two Competing Arginine Pathways in Macrophages. Front Immunol 5:532-532. https://doi.org/10.3389/fimmu.2014.00532

83. Wijnands KAP, Hoeksema MA, Meesters DM, van den Akker NMS, Molin DGM, Briedé JJ, Ghosh M, Köhler SE, van Zandvoort MAMJ, de Winther MPJ, Buurman WA, Lamers WH, Poeze M (2014) Arginase-1 deficiency regulates arginine concentrations and NOS2-mediated NO production during endotoxemia. PLoS One 9:e86135-e86135. https://doi.org/ 10.1371/journal.pone.0086135

84. Darcy CJ, Woodberry T, Davis JS, Piera KA, McNeil YR, Chen Y, Yeo TW, Weinberg JB, Anstey NM (2014) Increased plasma arginase activity in human sepsis: association with increased circulating neutrophils. Clin Chem Lab Med 52:573-581. https://doi.org/10.1515/cclm-2013-0698

85. Shiva S, Sack MN, Greer JJ, Duranski M, Ringwood LA, Burwell L, Wang X, MacArthur PH, Shoja A, Raghavachari N, Calvert JW, Brookes PS, Lefer DJ, Gladwin MT (2007) Nitrite augments tolerance to ischemia/reperfusion injury via the modulation of mitochondrial electron transfer. J Exp Med 204:2089-2102. https://doi.org/10.1084/jem.20070198 
86. Gonzalez FM, Shiva S, Vincent PS, Ringwood LA, Hsu L-Y, Hon YY, Aletras AH, Cannon RO 3rd, Gladwin MT, Arai AE (2008) Nitrite anion provides potent cytoprotective and antiapoptotic effects as adjunctive therapy to reperfusion for acute myocardial infarction. Circulation. 117:2986-2994. https://doi.org/10.1161/CIRCULATIONAHA.107.748814

87. Spronk PE, Ince C, Gardien MJ, Mathura KR, Oudemans-van Straaten HM, Zandstra DF (2002) Nitroglycerin in septic shock after intravascular volume resuscitation. Lancet. 360:1395-1396. https://doi.org/10.1016/s0140-6736(02)11393-6

88. Boerma EC, Koopmans M, Konijn A, Kaiferova K, Bakker AJ, van Roon EN, Buter H, Bruins N, Egbers PH, Gerritsen RT, Koetsier PM, Kingma WP, Kuiper MA, Ince C (2010) Effects of nitroglycerin on sublingual microcirculatory blood flow in patients with severe sepsis/septic shock after a strict resuscitation protocol: a double-blind randomized placebo controlled trial. Crit Care Med 38:93-100. https://doi.org/10.1097/CCM.0b013e3181b02fc1

89. Huellner MW, Schrepfer S, Weyand M, Weiner H, Wimplinger I, Eschenhagen T, Rau T (2008) Inhibition of aldehyde dehydrogenase type 2 attenuates vasodilatory action of nitroglycerin in human veins. FASEB J 22:2561-2568. https://doi. org/10.1096/fj.07-098830

90. Janero DR, Bryan NS, Saijo F, Dhawan V, Schwalb DJ, Warren MC, Feelisch M (2004) Differential nitros(yl)ation of blood and tissue constituents during glyceryl trinitrate biotransformation in vivo. Proc Natl Acad Sci U S A 101:16958-16963. https://doi.org/10.1073/pnas.0406075101

91. Trzeciak S, Glaspey LJ, Dellinger RP, Durflinger P, Anderson K, Dezfulian C, Roberts BW, Chansky ME, Parrillo JE, Hollenberg SM (2014) Randomized controlled trial of inhaled nitric oxide for the treatment of microcirculatory dysfunction in patients with sepsis*. Crit Care Med 42:2482-2492. https://doi.org/10.1097/ccm.0000000000000549

\section{Publisher's Note}

Springer Nature remains neutral with regard to jurisdictional claims in published maps and institutional affiliations.

\section{Submit your manuscript to a SpringerOpen ${ }^{\circ}$} journal and benefit from:

- Convenient online submission

- Rigorous peer review

- Open access: articles freely available online

High visibility within the field

- Retaining the copyright to your article

Submit your next manuscript at $\boldsymbol{\nabla}$ springeropen.com 